\title{
Effects of Imitation Writing on Writing Quality of English Majors with Different Proficiency
}

\author{
Chen Chen* \\ School of Foreign Languages \\ Taizhou University \\ Taizhou, Jiangsu Province, PRC
}

\begin{abstract}
This study was undertaken to investigate whether imitation writing had any effects on writing quality of English majors with different proficiency in terms of content, organization and language. Two research designs were made, an experiment and a questionnaire. All the data were collected by their writing teacher. Data analysis involved 4 steps: double scoring, calculating mean, comparing the mean differences and comparing the means by paired-samples t-test. The major findings yielded from this study are summarized as follows: Firstly, imitation writing has the greatest effect on writing quality of English majors with different proficiency in terms of content. Secondly, imitation writing also has a positive effect on English majors' writing quality in terms of organization. Thirdly, the same is true of the English majors' language in writing. Last but not least, the mean difference in the organization is not as great as the difference in language and content. Its significance lies in providing EFL teachers with some solutions to problems in English majors' writing in China, offering students valuable suggestions to reduce their anxiety and build up their writing confidence so as to improve their writing quality.
\end{abstract}

Keywords-meme; imitation writing; writing quality; English majors

\section{INTRODUCTION}

The researcher was motivated to conduct this study for two reasons: attempting to improve the inadequate English writing quality of English majors, and promoting the imitation writing in English majors' writing course.

On the one hand, as a means of communication, writing plays an increasingly crucial role in international affairs with the expansion of global communication and the advance of the information age. Of the four language skills, listening, speaking, reading and writing, writing reflects both learners' mastery of vocabulary and grammar and ability to organize, analyze, express and reason logically. Therefore, it is extremely important for English learners to equip themselves with the skill of writing.

On the other hand, the teaching of writing seems to be no easy job because of the constraint from limited teaching time, class size, teachers' proficiency and so on. Effective ways of

The paper is a part of the achievements of the project "Research on Collaborative Innovation of Digital Teaching Platform for English Majors" 2017SJB1913 that guides Universities' Philosophy and Social Science Researches in Jiangsu Province and the key project "Research on the Construction of Multi-language Translation Training Teaching Platform Based on Big Data" 2019JGB06 that guides Teaching Project of Taizhou University. teaching from various aspects and angles, like writing essence, writing process, and writing rules have been worked out, while the traditional imitation writing has ever encountered neglect and misunderstanding.

In the hope of promoting the effective writing teaching approach and improving the English majors' writing quality, researchers can integrate imitation writing with the memetic theory and applies it to the writing teaching.

\section{LITERATURE REVIEW}

\section{A. Key Terms in the Study}

1) Meme

The definition of meme remains a contested ontological question, which has been defined by many linguists and researchers from different perspectives. Dawkins gives the first definition to the word "meme" in his book The Selfish Gene, in which memes are treated as units of cultural transmission "which propagate them in the meme pool by leaping from brain to brain, from one generation to another via a process which, in the broad sense, can be called imitation" [1]. Dennett takes memes as information undergoing the evolutionary algorithm, whether they are in a brain, in a book or in some other physical objects[2]. In 1999, Dawkins's student Susan Blackmore completes the former's view about the meme. In her book The Meme Machine, Blackmore doesn't compare meme with the gene, but believes that the two have nothing in common except in way of "being replicated". Blackmore emphasizes that the definition of the meme "depends on, and should depend on, the concept of imitation". Anything "that can be passed on by imitation" can be counted as memes[3].

From the above definitions, the researcher thinks that Blackmore's definition is more reasonable and suitable, for she has integrated various people's researches, generalized the concept of the meme and revealed the new meaning of meme. Consequently, in this study, the author adopts Blackmore's definition of meme.

\section{2) Imitation writing}

Imitation is one of the most important means of learning a language. No one is born with the ability of writing. Blackmore points out that the real capacity of imitation only exits in a few species. In her opinion, the capacity of various 
and complicated imitation is unique to human and the complicated imitation process consists of three procedures:

a) Deciding what to imitate and how to make the "same" or "similar" imitation;

b) Accomplishing the complex transmission from one angle to others;

\section{c) Making matching body actions [4].}

However, imitation is not the goal, but only a way to improve one's writing skills. With the continuous improvement of imitating skills, students should learn to discard ready-made sentences and frames from model essays gradually, to master what they learn through a comprehensive study, and finally to carry on their own creative writing. Writing starts from imitation and one will raise his or her writing level through continuous imitation writing.

Based on the above researches, the researcher defines imitation writing as writing means that people imitate words and expressions, sentence patterns, structures, etc, from model essays to carry on their writing and that people use the enlightenment or the inspiration obtained from some articles in their own articles.

\section{B. Theoretical Foundations in the Study}

\section{1) Memetics}

Memetics arose in the 1990s to explore the concepts and transmission of memes in terms of an evolutionary model. First, memeticists seek to apply the techniques of epidemiology to the spread of beliefs and ideas through populations. Second, they analyze the relative prevalence of various memes and document their independent origins or common ancestry. Third, they also attempt to further explain, clarify, and quantify the theory of memes; and hope to use their theory to make predictions about how humans behave that go beyond what would be expected by evolutionary psychology or sociobiology, which assume genetic benefit to human behavior.

Obviously, memeticists would like to explore why humans alone have given rise to memes, why humans evolved as such good meme-spreaders, and why and how humans devote their energies to propagating both their genes and their memes in the modern world.

\section{2) Swain's output hypothesis}

According to Krashen, acquisition occurs naturally when learners are exposed to a large amount of comprehensible input. Swain provides a good summary of the roles that output plays in acquisition[5]. After many types of research, she generalized her ideas as the Output Hypothesis, which states that learners need the opportunity for meaningful use of their linguistic resources to achieve full grammatical competence.

As these points illustrate, the output is something that promotes how learners interact with input for the continued growth of their linguistic systems. Van Patten adds that output may help learners develop fluency. The more we practice accessing linguistic data from our implicit linguistic system, the more likely we are to develop fluency in the L2[6]. However, the output cannot replace input as the means by which acquisition takes place. In other words, the output can be critical to stimulate acquisition processes, but it cannot replace them. Thus, output works at retrieving language data while input is responsible for getting that data into the system.

Wang Haixiao proposed that researchers should turn their focus to the learning subject with the help of various auxiliary means such as database and network platform[7](in Chinese). In order not to increase the burden of students' recitation, the teaching mode of read-memory-discussion-writing not only emphasizes the cultivation of language skills, but also pays attention to the cultivation of students' logical thinking and innovation ability, which effectively promotes the realization of students' writing level from quantitative accumulation to qualitative change[8](in Chinese).

After many years' English teaching practice in china, educationists and teachers have realized that they should not only provide sufficient input in teaching Chinese students to speak and write in English but also help students find ways to train their productive skills and provide students with enough chance to practice English in and outside class.

\section{METHODOLOGY}

\section{A. Research Questions}

The research aims at investigating whether imitation writing has any effect on writing quality of English majors with different proficiency. Based on this point, we put forward the research questions in this study:

What effects does imitation writing have on writing quality of English majors with different proficiency in terms of content?

What effects does imitation writing have on writing quality of English majors with different proficiency in terms of organization?

What effects does imitation writing have on writing quality of English majors with different proficiency in terms of language?

\section{B. Research Designs}

The research began in September 2018 and lasted one week. As required by the syllabus of Advanced Writing for English majors at Taizhou University they have two lessons every week. The experiment in this study included participants, instruments, treatment, data collection and data analysis.

\section{1) Participants}

Participants in this study contain 30 students and the writing teacher. The teacher is a Ph.D., who is very skillful and teaches Advanced Writing for more than five years. The students are sophomore students majoring in English at the School of Foreign Languages, Taizhou University. They were selected simply because they had gained enough writing experience and thus, were linguistically competent to do the writing test, especially in argumentative writing.

\section{2) Instruments}

The instruments involved two writing tests: a pre-test and a post-test, sharing with the same writing topic 
1) Effects of imitation writing on high achievers' writing quality in terms of content

TABLE II. HIGH ACHIEVERS’ PAIRED-SAMPLES T-TEST IN TERMS OF CONTENT

The treatment in this study involves two writing tasks: a writing-only task and an imitation-writing task. In a writingonly task, students were required to write a composition of about 200 words on the following topic: "Will Tourism Bring Harm to the Environment?” in 45 minutes. One week later, the imitation-writing task was assigned, in which two model essays were first handed out, and then students were asked to read them at their own pace and then write on the same topic. The time limit for their reading and writing was 65 minutes. The two model essays in the imitation-writing task were sought on our research team's self-built platform, "Digital Teaching Platform for English Majors of Taizhou University”, which was selected according to the following criteria: approximately two hundred words; clear argument; clear main idea; well organized and perfectly coherent; with effective choice of words and full control of complex structures.

\section{4) Data collection}

Both the pre-test writing and the post-test writing were undertaken in regular classes. The former was employed in the first week and the latter in the next week. All the pieces of writing by the subjects during the pre-test and post-test were mixed up and scored together so that the teachers would not show bias in marking them.

\section{5) Data analysis}

Data analysis involved double scoring, calculation and comparison. The present study made use of SPSS (22.0 version)-the Statistical Package for Social Science, which is powerful and popular in both social science and educational analysis, to do the work of data analysis of the experiment.

\section{RESUlTS AND DisCUSSION}

A. Effects of Imitation Writing on Writing Quality of English Majors with Different Proficiency in Terms of Content

TABLE I. PAIRED-SAMPLES T-TEST IN TERMS OF CONTENT

\begin{tabular}{|c|c|c|c|c|c|c|}
\hline Content & $\mathbf{N}$ & $\mathbf{X}$ & $\begin{array}{c}\text { Mean } \\
\text { difference }\end{array}$ & SD & t & P \\
\cline { 1 - 3 } Pre-test & 30 & 22.0333 & -3.10000 & 2.72262 & \multirow{2}{*}{-7.125} & \multirow{2}{*}{.000} \\
\cline { 1 - 3 } Post-test & 30 & 25.1333 & & 2.06336 & & \\
\hline
\end{tabular}

Paired-samples T-test in terms of content

The total score in the part of the content is 30. It can be seen from the table that the means of content in the pre-test and the post-test were 22.0333 and 25.1333 respectively, and their standard deviations are 2.72262 and 2.06336 respectively. The mean difference was 3.10000 with the significant level at .000 $<.001$, that is to say, scores in the second writing is much higher than those of the first writing. In a word, imitation writing has a positive effect on English majors' writing ability in terms of content.

\begin{tabular}{|c|c|c|c|c|c|c|}
\hline Content & $\mathbf{N}$ & $\mathbf{X}$ & $\begin{array}{c}\text { Mean } \\
\text { difference }\end{array}$ & SD & t & P \\
\hline \multicolumn{7}{|c|}{ Cont. to TABLE II. } \\
\cline { 1 - 5 } Pre-test & 6 & 25.1667 & -2.00000 & 1.47196 & -2.928 & \multirow{2}{*}{.033} \\
\hline Post-test & 6 & 27.1667 & & 1.16905 & & \\
\hline
\end{tabular}

High achievers' paired-samples T-test in terms of content

It can be seen from Table II that the means of content in the pre-test and the post-test were 25.1667 and 27.1667 respectively, and their standard deviations were 1.47196 and 1.16905 respectively. The mean difference was 2.00000; with a significant level at $.033<.05$, which shows a difference in writing quality in terms of the content of the two tests; and high achievers' scores in content increased in the post-test.

2) Effects of imitation writing on middle achievers' writing quality in terms of content

TABLE III. MIDDLE ACHIEVERS' PAIRED-SAMPLES T-TEST IN TERMS OF CONTENT

\begin{tabular}{|c|c|c|c|c|c|c|}
\hline Content & N & $\mathbf{X}$ & $\begin{array}{c}\text { Mean } \\
\text { difference }\end{array}$ & SD & $\mathbf{t}$ & $\mathbf{P}$ \\
\cline { 1 - 2 } Pre-test & 13 & 22.3846 & -2.38462 & 1.75777 & \multirow{2}{*}{-4.251} & .001 \\
\cline { 1 - 2 } Post-test & 13 & 24.7692 & & 2.00640 & \\
\hline \multicolumn{7}{|c|}{ Middle achievers' paired-samples T-test in terms of content }
\end{tabular}

It can be seen from Table III that the means of content in the pre-test and the post-test were 22.3846 and 24.7692 respectively. The mean difference was 2.38462; with a significant level at .001<.05; i.e., middle achievers' scores in the second writing are higher than those of the first writing.

3) Effects of imitation writing on low achievers' writing quality in terms of content

TABLE IV. LOW ACHIEVERS’ PAIRED-SAMPLES T-TEST IN TERMS OF CONTENT

\begin{tabular}{|c|c|c|c|c|c|c|}
\hline Content & N & $\mathbf{X}$ & $\begin{array}{c}\text { Mean } \\
\text { difference }\end{array}$ & SD & t & P \\
\hline Pre-test & 11 & 19.9091 & -4.54545 & 2.38556 & -5.926 & .000 \\
\cline { 1 - 2 } & 11 & 24.4545 & & 1.91644 & & \\
\hline
\end{tabular}

Low achievers' paired-samples T-test in terms of content

Based on Table IV, as for low achievers, the means of content in the pre-test and the post-test were 19.9091 and 24.4545 respectively. The mean difference is 4.54545 ; with a significant level at $.000<.001$, which is a significant difference between pretest and post-test.

4) Discussion of effects of imitation writing on writing quality of English majors with different proficiency in terms of content

TABLE V. MEAN DIFFERENCES OF ENGLISH MAJORS WITH DIFFERENT PROFICIENCY IN TERMS OF CONTENT

\begin{tabular}{|c|c|c|c|c|}
\hline $\begin{array}{c}\text { Mean } \\
\text { difference }\end{array}$ & $\begin{array}{c}\text { High } \\
\text { achiever }\end{array}$ & $\begin{array}{c}\text { Middle } \\
\text { achiever }\end{array}$ & $\begin{array}{c}\text { Low } \\
\text { achiever }\end{array}$ & Overall \\
\hline Content & -2.00000 & -2.38462 & -4.54545 & -3.10000 \\
\hline
\end{tabular}


mean difference was 1.0000 with a significant level at $.012<.05$

Based on the statistics above, students' writing in content shows a significant improvement, with high achiever's 2.00000, middle achiever's 2.38462 and low achiever's 4.54545. In addition, low achiever presents a greater increase than the other two groups do, which is nearly double that of the middle and over twice that of the high. That is to say, imitation writing is significantly effective in improving English majors' content in writing, especially to those students with low proficiency. This may be due to the following two reasons:

For one thing, high achievers are particularly qualified to use powerful and relevant arguments to support their opinions, and employ appropriate and convincing evidence to support the arguments; hence their room of improvement should be limited after only one practice of imitation writing.

For another, to ensure the majority of the participants' comprehension of the model texts, the selected models are moderate in length and degree of difficulty; which may be rather near to high achievers' writing in terms of content; and, of course, not so effective to the high as it to the middle and the low.

Moreover, two students who had achieved the greatest improvement in content were selected to analyze qualitatively. In the second writing task, their scores in content increased by 8 points, with one from 16 to 24 points and the other from 20 to 28 points.

\section{B. Effects of Imitation Writing on Writing Quality of English Majors with Different Proficiency in Terms of Organization}

TABLE VI. PAIRED-SAMPLES T-TEST IN TERMS OF ORGANIZATION

\begin{tabular}{|c|c|c|c|c|c|c|}
\hline Organization & $\mathbf{N}$ & $\mathbf{X}$ & $\begin{array}{c}\text { Mean } \\
\text { difference }\end{array}$ & SD & t & P \\
\cline { 1 - 3 } Pre-test & 30 & 22.0000 & 0.83333 & 2.01717 & \multirow{2}{*}{-3.068} & \multirow{2}{*}{.005} \\
\cline { 1 - 3 } & 30 & 22.8333 & & 2.11861 & \\
\hline
\end{tabular}

Paired-samples T-test in terms of organization

In the part of the organization, the total score is 30 . As is shown in Table VI, the means of organization in the pre-test and the post-test were 22.0000 and 22.8333 respectively. The mean difference was 0.83333 with the significant level at .005 $<.05$, which shows a difference in the aspect of organization of the two tests. In other words, imitation writing seems to have some positive effects on English majors' writing quality in terms of organization.

1) Effects of imitation writing on high achievers' writing quality in terms of organization

TABLE VII. HIGH ACHIEVERS' PAIRED-SAMPLES T-TEST IN TERMS OF ORGANIZATION

\begin{tabular}{|c|c|c|c|c|c|c|}
\hline Organization & $\mathbf{N}$ & $\mathbf{X}$ & $\begin{array}{c}\text { Mean } \\
\text { difference }\end{array}$ & SD & $\mathbf{t}$ & $\mathbf{P}$ \\
\cline { 1 - 3 } Pre-test & 6 & 24.5000 & -1.0000 & .83666 & - & \multirow{2}{*}{.012} \\
\cline { 1 - 3 } & & 25.5000 & .54712 & 3.873 & \\
\hline
\end{tabular}

High achievers' paired-samples T-test in terms of organizatio

As shown in Table VII, the means of organization in the pre-test and the post-test were 24.5000 and 25.5000; and their standard deviations are .83666 and .54712 respectively. The which shows significant progress in the organization.

2) Effects of imitation writing on middle achievers' writing quality in terms of organization

TABLE VIII. MIDDLE ACHIEVERS’ PAIRED-SAMPLES T-TEST IN TERMS OF ORGANIZATION

\begin{tabular}{|c|c|c|c|c|c|c|}
\hline Organization & $\mathbf{N}$ & $\mathbf{X}$ & $\begin{array}{c}\text { Mean } \\
\text { difference }\end{array}$ & SD & $\mathbf{t}$ & $\mathbf{P}$ \\
\cline { 1 - 3 } Pre-test & 13 & 22.3077 & \multirow{2}{*}{-.07692} & 1.43670 & - & \multirow{2}{*}{.808} \\
\cline { 1 - 3 } & 13 & 22.3846 & & 1.55662 & .249 & \\
\hline
\end{tabular}

Middle achievers' paired-samples T-test in terms of organization

From Table VIII, the means of organization in the pre-test and the post-test were 22.3077 and 22.3846 respectively. The mean difference was -.07692, with the significant level at .808>.050, which is not a significant difference, but still shows an improvement in the organization.

3) Effects of imitation writing on low achievers' writing quality in terms of organization

TABLE IX. LOW ACHIEVERS’ PAIRED-SAMPLES T-TEST IN TERMS OF ORGANIZATION

\begin{tabular}{|c|c|c|c|c|c|c|}
\hline Organization & $\mathbf{N}$ & $\mathbf{X}$ & $\begin{array}{c}\text { Mean } \\
\text { difference }\end{array}$ & SD & $\mathbf{t}$ & $\mathbf{P}$ \\
\cline { 1 - 3 } Pre-test & 11 & 20.2727 & \multirow{2}{*}{-1.63636} & 1.34840 & - & \multirow{2}{*}{013} \\
\cline { 1 - 3 } Post-test & 11 & 21.9091 & & 2.11918 & 3.008 & \\
\hline
\end{tabular}

Low achievers' paired-samples T-test in terms of organization

From Table IX, the means of organization in the pre-test and the post-test were 20.2727 and 21.9091 respectively. The mean difference was 1.63636, with the significant level at $.013<.05$. That is to say, scores in the aspect of organization in the second writing increased and imitation writing helps to improve low achievers' writing quality in terms of organization.

4) Discussion of effects of imitation writing on writing quality of English majors with different proficiency in terms of organization

TABLE X. MEAN DIFFERENCES IN ENGLISH MAJORS WITH DIFFERENT PROFICIENCY IN TERMS OF ORGANIZATION

\begin{tabular}{|c|c|c|c|c|}
\hline $\begin{array}{c}\text { Mean } \\
\text { difference }\end{array}$ & $\begin{array}{c}\text { High } \\
\text { achiever }\end{array}$ & $\begin{array}{c}\text { Middle } \\
\text { achiever }\end{array}$ & $\begin{array}{c}\text { Low } \\
\text { achiever }\end{array}$ & Overall \\
\hline Organization & -1.00000 & -0.07692 & -1.63636 & -0.83333 \\
\hline
\end{tabular}

Mean differences in English majors with different proficiency in terms of organization

As shown in Table X, students' writing organization in the post-test improved by 0.83333 , with high achiever's 1.00000 , middle achiever's 0.07692 and low achiever's 1.63636. Comparatively speaking, low achievers' progress is more significant than those of the other two groups.

That is to say, imitation writing is rather effective to improve low achievers' organizing in writing. This should be attributed to the fact that students with high proficiency know well about how the text is organized and how paragraphs are developed in good writing, so that they probably do not focus on the rhetorical organizations of the models, which is well organized and perfectly coherent. However, since low achievers have no confidence to develop several paragraphs with appropriate organization and coherence in argumentative 
writing, they tend to depend more on the models by imitating the structure; which results in more remarkable headway.

\section{Effects of imitation writing on writing quality of English majors with different proficiency in terms of language}

TABLE XI. PAIRED-SAMPLES T-TEST IN TERMS OF LANGUAGE

\begin{tabular}{|c|c|c|c|c|c|c|}
\hline Language & $\mathbf{N}$ & $\mathbf{X}$ & $\begin{array}{c}\text { Mean } \\
\text { difference }\end{array}$ & SD & $\mathbf{t}$ & P \\
\cline { 1 - 1 } Pre-test & 30 & 29.0667 & -2.4333 & 3.26880 & - & \multirow{2}{*}{.000} \\
\cline { 1 - 3 } & & 2.96822 & 5.873 & \\
\hline
\end{tabular}

Paired-samples T-test in terms of language

In the current study, the total score for language is 40. As Table XI shows, the mean in the pre-test was 29.0667, and 31.5000 in the post-test. The standard deviations in the pre-test and the post-test were 3.26880 and 2.96822 respectively. The mean difference was 2.4333 with the significant level at .000 $<.001$, in other words, students made better performance in the post-test. There is a significant difference in language between the two tests.

1) Effects of imitation writing on high achievers' writing quality in terms of language

TABLE XII. HIGH ACHIEVERS' PAIRED-SAMPLES T-TEST IN TERMS OF LANGUAGE

\begin{tabular}{|c|c|c|c|c|c|c|}
\hline Language & $\mathbf{N}$ & $\mathbf{X}$ & $\begin{array}{c}\text { Mean } \\
\text { difference }\end{array}$ & SD & $\mathbf{t}$ & $\mathbf{P}$ \\
\hline Pre-test & 6 & 33.8333 & \multirow{2}{*}{-1.66667} & 1.47196 & \multirow{2}{*}{$\begin{array}{c}- \\
1.976\end{array}$} & \multirow{2}{*}{.105} \\
\hline Post-test & 6 & 35.5000 & & 1.04881 & & \\
\hline
\end{tabular}

High achievers' paired-samples T-test in terms of language

As Table XII shows, the mean in the pre-test was 33.8333, and 35.5000 in the post-test; and their standard deviations are 1.47196 and 1.04881 respectively. The mean difference is 1.66667, with the significant level at .105>.05, in other words, high achievers make comparatively better performance in the post-test. However, it is not a significant difference in language between the two tests.

2) Effects of imitation writing on middle achievers' writing quality in terms of language

TABLE XIII. MIDDLE ACHIEVERS' PAIRED-SAMPLES T-TEST IN TERMS OF LANGUAGE

\begin{tabular}{|c|c|c|c|c|c|c|}
\hline Language & $\mathbf{N}$ & $\mathbf{X}$ & $\begin{array}{c}\text { Mean } \\
\text { difference }\end{array}$ & SD & $\mathbf{t}$ & $\mathbf{P}$ \\
\cline { 1 - 5 } Pre-test & 13 & 29.0769 & -2.0000 & 1.97744 & - & \multirow{2}{*}{.003} \\
\cline { 1 - 3 } Post-test & 13 & 31.0769 & 2.21591 & 3.766 & \\
\hline
\end{tabular}

As is shown in Table XIII, the mean in the pre-test was 29.0769, and 31.0769 in the post-test. The mean difference is 2.0000 , with a significant level at $.003<.050$, which shows a difference in writing quality in terms of the language of the two tests. In a word, imitation writing seems to have some positive effects on middle achievers' writing quality in terms of language.
3) Effects of imitation writing on low achievers' writing quality in terms of language

TABLE XIV. LOW ACHIEVERS' PAIRED-SAMPLES T-TEST IN TERMS OF LANGUAGE

\begin{tabular}{|c|c|c|c|c|c|c|}
\hline Language & $\mathbf{N}$ & $\mathbf{X}$ & $\begin{array}{c}\text { Mean } \\
\text { difference }\end{array}$ & SD & $\mathbf{t}$ & P \\
\cline { 1 - 1 } Pre-test & 11 & 26.4545 & \multirow{2}{*}{-3.36364} & 2.01810 & - & \multirow{2}{*}{.002} \\
\cline { 1 - 2 } & 11 & 29.8182 & & 2.48267 & 4.261 & \\
\hline
\end{tabular}

Low achievers' paired-samples T-test in terms of language

According to Table XIV, low achievers' mean of language in the pre-test and the post-test are 26.4545 and 29.8182 respectively. The mean difference is 3.36364 , with the significant level at $.002<.05$, that is to say, low achievers gained a great improvement in the aspect of language in the post-test.

4) Discussion of effects of imitation writing of writing quality on English majors with different proficiency in terms of language

TABLE XV. MEAN DIFFERENCES IN ENGLISH MAJORS WITH DIFFERENT PROFICIENCY IN TERMS OF LANGUAGE

\begin{tabular}{|c|c|c|c|c|}
\hline $\begin{array}{c}\text { Mean } \\
\text { difference }\end{array}$ & $\begin{array}{c}\text { High } \\
\text { achiever }\end{array}$ & $\begin{array}{c}\text { Middle } \\
\text { achiever }\end{array}$ & $\begin{array}{c}\text { Low } \\
\text { achiever }\end{array}$ & Overall \\
\hline Language & -1.66667 & -2.00000 & -3.36364 & -2.43333 \\
\hline
\end{tabular}

Mean differences in English majors with different proficiency in terms of language

Table XV indicates that the mean differences of high achievers, the middle ones and the low ones are 1.66667, 2.00000 and 2.43333 respectively. This means that low achievers' improvement is largest; the middle achievers' is in moderation, and the high ones' is lest.

In short, imitation writing exerts positive effects on English majors' writing quality in terms of language. All students, including high achievers, middle ones and low ones, made progress in the post-test. While the improvement of students with low proficiency shows that imitation writing is more effective to them than it is to the middle and the high. First, this is caused by high achievers' comparatively limited room of improvement in language, because they are linguistically competent to make their writing with effective choice of words, complex sentence patterns and fewer language errors. However, low achievers fail to do this, so they need to try to search useful words, phrases, well-written sentences and paragraphs in the models, which in turn benefit their writing dramatically. Second, this also comes from the models' election, which is neither too easy, nor too difficult, thus they are more effective to students with middle or low proficiency.

Students' significant improvement in the language in their second writing may be attributed to the following two reasons.

Firstly, the model essays offer a large number of alternatives to useful words, phrases and sentence patterns. Effective choice of words and full control of complex structures were part of the criteria by which the model essays were selected. Those words and phrases which they were not sure were replaced by useful expressions and the language forms provided by the model essays. 
The other possible reason for this is that students had done a writing task before they read the model essays on the same topic, which made them pay more attention to expressions and language forms in the model essays. One week ago, when students did the first writing, they realized that they could not express themselves exactly and clearly. This, in turn, prompted them to search in the model essays for useful words and expressions which they wanted in their second writing. Furthermore, writing on the issue again after reading the model essays provided students with the opportunity to practice new words and expressions, which help them to achieve accuracy in the target language.

\section{CONCLUSION}

\section{A. Major findings of this study}

Generally speaking, the major findings of this study could be summarized from the following aspects:

Firstly, the imitation writing approach is particularly effective in writing quality of English majors with different proficiency in terms of content.

Secondly, imitation writing also has a positive effect on English majors' writing quality in terms of organization. That is to say, imitation writing has positive effects on English majors' organizing in writing, which plays a bigger role in improving the organization of the low achievers.

Thirdly, imitation writing exerts a positive effect on putting forward English majors' language in writing. Specifically, their second writing involves fewer language errors, more effective choice of words and more complex sentence structures; especially to those students with low proficiency.

Last but not least, the mean difference in the organization is not as great as those in the other two parts: language and content. Students showed much less improvement in an organization than they did in language and content in the second writing task.

\section{B. Pedagogical implications}

This research provides inspiration for the teaching of English writing, from which the author generalizes some factors which can influence the application of imitation writing to English majors' writing.

1) Selection of model texts. If the texts are moderate in length, it can be easily comprehended by learners. Too long texts may frustrate learners' confidence, while too short materials can't provide sufficient knowledge. Therefore, writing teachers can integrate relevant, comprehensible, and interesting materials into their teaching, which should be comprehensible for students with their current language competence while at the same time covering vocabulary, sentence patterns and structures that are a bit beyond their ability. After being analyzed by the teacher, the difficult parts are noticed and comprehended by students and thus are capable of being assimilated and imitated.

2) Analysis and explanation of model texts. It is necessary for teachers to offer an overall explanation of the materials and subtle analysis of the text structure and content. Some unfamiliar words or expressions may hind students' comprehension. Since students seldom pay attention to rhetorical organization, teachers should not only lead students to understand the text, but also encourage them to grasp the text structure and organization and ways of writing of the model texts. The more attention they pay to how the texts are developed and organized, the better will students benefit from the imitation.

3) Suitable inspection and supervision. Since writing, imitation, and association need imagination and great perseverance, suitable inspection and supervision are essential to teachers. Considering the discrepancy of students, teachers should make a difference in requirements between them.

4) Awareness of students' attitudes. As the main body of learning, teachers should guide students to cultivate their interests and build self-confidence in writing; and endeavor to help students form good habits and clear up a misconception on writing course. Furthermore, teachers should help students grope for and sum up appropriate strategies for their own learning habits in the course of teaching and learning. Meanwhile, teachers should encourage students to get over difficulty and complete assignments effectively.

Since imitation writing is more effective to students with low proficiency, it is advisable to explore appropriate ways to improve the application of imitation writing to English majors, e. g., teachers can employ stratify teaching in writing course, or select different model texts for students with different proficiency.

\section{REFERENCES}

[1] Dawkins, R., “The selfish gene”, Oxford: Oxford University Press, 2006.

[2] Dennett, D.C., "Darwin's dangerous idea. Evolution and the meanings of life”, New York: Simon \& Schuster, 1995, pp.234-236.

[3] Blackmore, S. "The meme machine”, Oxford: Oxford University Press, 2000.

[4] Blackmore, S., "Evolution and memes: The human brain as a selective imitation device”, Cybernetics and Systems, 2001, 32: 225-255.

[5] Swain, M., "Communicative competence: Some roles of comprehensible input and comprehensible output in its development", Cambridge: Cambridge University Press, 1985.

[6] Patten, V. B., "From input to output: A teacher's guide to second language acquisition”, New York: McGraw-Hill, 2003.

[7] Haixiao Wang, "Reform in the teaching of college English writing in the big data era”, Modern Distance Education Research, 2014, (3):66-72. ( In Chinese)

[8] Yunhua Deng and Jia Yi, “A teaching model of college English writing from the memetic perspective”, Technology Enhanced Foreign Language Education, 2016, (6): 3-8. ( In Chinese) 